on the first two floors for the commercial department where the latest contrivances for mechanizing arithmetic may be seen. On the central portion of the first floor-reached either by stairs or lift-are the library, board room, Retail Trades and Commodities Room. Between the upper part of the assembly hall and the library is a wide corridor lined with many fine pictures. In fact, the portion directly over the foyer is called the Picture Gallery. Directly above the assembly hall on the second floor is the cafeteria and dining hall fitted with a complete kitchen unit.

Behind the main building and connected by covered corridors are the departments of science and engineering, with a car park between them. At present, these are on the ground floor, but the science block will eventually be enlarged by the addition of two more floors. It now comprises laboratories for biology, building science, chemistry and physics, all equipped with the most modern appliances. It is anticipated to develop specialized courses with particular reference to the needs of local industries, for in the neighbourhood there are several large manufacturing chemists, an important cement works and one of the largest factories in the country for the production of photographic materials. Co-operation with some of these has already been established.

In the engineering block are to be found workshops for carpentry, automobile construction, plumbing, electrical installation and machine tools, each of which is thoroughly equipped with the latest machinery, all unit driven. There are also a spacious drawing office and an applied mechanics laboratory. As in the case of the science department, it is hoped to correlate the work done with local industries, and already the Ford Motor Company is sending a large number of employees to the college for instruction.

Here, indeed, is a worthy institution wherein to "find out what a man can do and then teach him to do it better".

\title{
Excavations at Chandhu- Daro, Sind
}

\begin{abstract}
CHANDHU-DARO, a mound site near Sukhpur $G$ in the Nawabshah District of Sind, was selected for investigation by the American School of Indic and Iranian Studies, with the active support of the Boston Museum of Fine Arts, in the hope that it would afford evidence bearing on the beginnings of the Harappa civilization, as known from the sites of Mohenjo-daro and Harappa in the Indus valley, or alternatively on the dark period between the dis. appearance of that civilization and the entry into India of the Aryan-speaking peoples at about 1500 B.C. The excavations have been conducted by Dr. E. J. A. Mackay, who described their progress to date before the Royal Society of Arts at a meeting on March 5.

The site of Chandhu-daro, situated east of the River Indus and eighty miles south-west of Mohenjodaro, consists of a complex of two large mounds and one small mound. In ancient times they constituted a single city, which was cut right through by flood water of the Indus, a disaster which led to the city being abandoned. There is indisputable evidence that a similar disaster occurred on more than one occasion and as Mohenjo-daro also suffered similarly from flood on at least two occasions, it is now thought probable that the decline of this great civilization may have been due to the impossibility of occupying sites that were continually being surrounded by large sheets of water.
\end{abstract}

Although the city in size never approached that of Mohenjo-daro, a massive wall, averaging five feet wide and traced for eighty feet, which was among the earliest discoveries, suggests that the city was of considerable importance.

In order to ascertain whether the site had been occupied by any peoples earlier than those of the Harappa culture, Mound II was examined to its lowest levels by a pit which was taken down to water-level. It then appeared that some five thousand years ago Mounds I and II had constituted a single city, as already mentioned. In this part of the site, at least, no culture lay between subsoil water, which was reached at twenty-five feet below plain level, and the mound above. The lowest levels at Chandhu give the impression of being earlier than the strata immediately above water-level at Mohenjo-daro.

There are no less than five Harappa occupations. They were separated by layers of debris, and there could be no doubt, as there is at Mohenjo-daro, as to where one occupation ended and another began. Whether there are other occupations below waterlevel, it is impossible to say. The water-level has risen considerably. Of the five levels, the two uppermost on Mound II only have as yet been cleared, and the three lower are still to be examined. In the earlier of the upper Harappa levels the most striking feature is the existence of a bathroom in practically every house and the elaborate and careful system of drainage. There can be little doubt that bathing must have been a ritual. Where smaller and less important houses were not connected with street drainage, a system of cesspits or storage vessels was employed. In the main street of the second Harappa level a remarkable building was unearthed, which seems to have been some kind of a Turkish bath, with small chambers situated over flue holes. There is no other evidence that the ancient peoples of India used hot-air baths, but a somewhat similar building was discovered at Mohenjo-daro.

The buildings of the last Harappa occupation were the better preserved, but the area of occupation was very much less. Not long after the site had been abandoned, it was occupied again about 2000 B.C. by a small community of unknown origin, the Jhukar, living in houses of matting or mud. Of these dwellings all traces have disappeared, except the remains of the floors and the fireplaces, which were practically unknown among the Harappa people, who used open hearths.

After the disappearance of the Jhukars, Mound II was occupied once more by a small community, who used hand-made, polished, grey ware already known as the Jhangar culture from the site of that name in Sind.

The pottery from Chandhu-daro is perhaps the most interesting that has been found on any ancient site in recent years. The painted ware is quite 
distinctive, and can be confused with no other ware. Unfortunately, few jars have been found complete. As on a similar ware at Mohenjo-daro, the motifs are painted in a thick black paint on a highly burnished red slip, which is almost like lacquer. Among the motifs is a quadruped with an exaggerated plumelike tail, a peacock with a crest of bush or tree-like form, while another bird has a crest which terminates in two sun-motifs. The sun apparently is conceived as a rotating sphere with prominences, while the association of the sun with vegetation is indicated by plant or bud designs, which represent these solar prominences. The larger storage vessels are frequently decorated around the upper part only. Incised decoration of pottery is comparatively rare.

The pottery of the Jhukar people in fabric, mode of decoration and polychrome colouring is quite different from that of their predecessors. Violet-black paint was applied to a thick cream slip. Below the decorative border are bands of red paint. Nor have the shapes any relation to the earlier wares. A clue to origin is afforded by a herring-bone pattern painted alternately in red and black, which recalls the much earlier ornamentation on wares from Tell Halaf in Mesopotamia and that found by Sir Aurel Stein at Zayak in southern Baluchistan. One triple vessel of the Jhangar grey ware also recalls a find made by Sir Aurel Stein at Shahi-tump in Baluchistan. This suggests that these people too may have entered India from the west, and possibly at a much earlier date than has been thought.

The seals used by the Harappa people are like those found at Mohenjo-daro; but those of the Jhukar are more primitive, and for the most part made of pottery. In the Harappa period, Chandhu- daro was a great centre of bead making, and beads have been found in all stages from the raw material to the finished bead. Among them were the cornelian beads ornamented with designs in white, such as have been found in Sumer, but now known to have been manufactured in India or by Indians.

Metal working in copper and bronze was a craft that was largely practised. Heavy blade axes, a scoop, new to the ancient world, knives, daggers, razors in three shapes, and hairpins all show great experience in metal working.

A large number of toys of various kinds were found, and nearly every child must have had a toy cart, usually made in pottery and closely following the real cart in detail. Pottery rattles, owing to their substantial make, are rarely found broken. Of objects connected with religion, the most interesting are the figurines of the mother goddess, which are very different from the cult images of the goddess found at Mohenjo-daro. They were without legs, but had a hollow base to stand on. Like other figures of the Harappa culture, they were richly loaded with jewellery and their ears were pierced for ear-rings. Little jewellery was found.

Although the unique objects found on the site naturally have remained in India, the Archæological Survey has been generous in the allocation of objects to the Boston Fine Arts Museum. This is the only collection of objects illustrative of the early Indian civilization on exhibition outside India, and it is to be regretted that no similar collection is to be found in the museums of Great Britain. The exploration of the many sites of importance in India should not be left to other countries, and no British expedition organized to work in this most promising field.

\section{Canadian Hydro-electric Power Development in 1936}

\begin{abstract}
$\mathrm{A}^{\mathrm{L}}$ THOUGH the actual output of electricity in Canada during 1936 reached the new high level of $25,493 \frac{1}{2}$ million kilowatt-hours, the year was not specially remarkable for progress in development of the available water supplies. The annual review of hydro-electric power progress, issued by the Canadian Minister of Mines and Resources on January 1 of this year, shows that a comparatively small addition was made to the preceding year's aggregate of water-power developed in the Dominion, which at the end of 1935 had attained a figure of $7,909,115$ horse-power. New installations during the twelve months increased this by 36,475 to the new total of $7,945,590$. This is a little short of 8 millions, and, as the estimated total available is fully 40 millions, represents barely twenty per cent of the country's resources.

Notwithstanding the relatively small increment for the year, there is a number of projects actually under way which will add materially to the aggregate during the course of the next year or two. The progress of hydro-electric development in Canada within recent years has been largely influenced by the conditions arising out of a period of restricted output, lasting from 1930 until 1933 . Prior to 1930 , a number of important installations had been made in order to keep pace with a steadily growing demand for power
\end{abstract}

which, however, slackened and ceased about six years ago. It was not until May 1933 that the demand resumed an upward tendency which has continued. But it produced a corresponding relaxation of effort in regard to new enterprises, the effect of which has not yet quite dissipated itself, though there is every likelihood of its doing so in the very near future.

The new installations during 1936 consisted chiefly of additions to existing stations at High Falls (a fourth unit of 30,000 horse-power), on the Lievre River in the Province of Quebec, by the Maclaren-Quebec Power Co.; at Rat Rapids (a new unit of 1,750 horse-power), on the Albany River in the Province of Ontario ; and at Ruth Falls $(4,300$ horse-power) on East River Sheet Harbour, Nova Scotia. Several small installations have also been completed in British Columbia.

The Quebec Streams Commission has continued to maintain satisfactorily the desired regulation of flow on all the controlled rivers in the province by means of its extensive system of storage reservoirs, of which there are now seventeen, some of them of considerable size. It is actively pursuing investigations in regard to other available storage sites with the view of adapting them to the same purpose. BRysson CUNNINGHAM. 